\title{
Systémy paliativní péče - mezinárodní srovnání ČR a Irsko - Lessons Drawing (čerpání ponaučení) Matěj Lejsal, Jiř́ Krejčí
}

\begin{abstract}
Abstrakt:
Hospicová a paliativní péče v Česku byla od počátku významně orientována na praxi. Postupně přibyla odborná specializace lékařů, odborné vzdělávání všeobecných sester. Rostoucí povědomí a zájem odborné i laické veřejnosti, včetně politické reprezentace, s sebou nese potřebu zakotvit paliativní péči do systému jednotlivých oborů sociální politiky jako její plnohodnotnou součást. Cílem srovnání strategických dokumentů a procesů v oblasti paliativní péče v Česku a Irsku prostřednictvím přehledové studie je přispět k „načerpání ponaučení" (Lessons Drawing) pro formování dalšího vývoje paliativní péče v ČR.
\end{abstract}

Klíčová slova: paliativní péče, mezinárodní srovnání, Irsko, modely, koncepce, národní klinický program, rozvoj, advocacy

Paliativní péči je v posledních letech věnována v Česku velká pozornost, získává své místo v krajských strategických dokumentech, $\mathrm{v}$ úhradových mechanismech fondů veřejného zdravotního pojištění i v legislativě. Změny jsou často iniciovány „zdola“. Paliativní péče je svou podstatou péče mezioborová. Přesto se řada změn děje izolovaně v jednotlivých oborech sociální politiky (v politice zdraví, vzdělávání, sociální bezpečnosti) ${ }^{1}$. Česko nemá jednotící vizi a strategii jejího naplnění, jakkoliv je možné dílčí úsilí sledovat například na krajské úrovni. Zakotvení paliativní péče jako systémového prvku v sociální politice, zejména v politice zdraví, může být nahlíženo jako proces změny velkého rozsahu. Vyžaduje sdílenou vizi řady aktérů, zavedení nových prvků do systému. Jde především o nové služby, nové odbornosti, nové nástroje financování. Nedílnou součástí celého procesu je nastavení vzájemných vztahů mezi existujícími a novými prvky a nastavení souvisejících procesů (předávání informací, finanční vztahy) a jejich zakotvení v legislativě, v odborné prrípravě i v praxi. Nedílnou součástí je i zvyšování povědomí a zájmu o nové prvky mezi odbornou i laickou veřejností. Při tvorbě politik je legitimním nástrojem „lessons drawing“ ze zahraniční zkušenosti přijímané v různé intenzitě. ${ }^{2} \mathrm{~V}$ rámci provedené česko-irské studie jsou porovnávány tř̀i základní oblasti: přístup k paliativní péči, strategické dokumenty a dominantní aktéři na národní úrovni. Výchozím zdrojem byly veřejně dostupné dokumenty (policy papers,

Igor TOMEŠ, Obory sociální politiky, Praha: Portál, 2011.

2 Colin C. WILLIAMS a kol., Assessing the cross-national transferability of policy measures for tackling undeclared work, GREY Working Paper No. 5, University of Sheffield, 2014. 
strategie, metodiky, profily organizací, viz níže) doplněné polostrukturovanými rozhovory se sedmi respondenty, kteří byli identifikováni dle profese (sociální pracovnice, zdravotní sestry, lékaři, ředitelka) a typu organizace (lůžkový hospic, stacionářr, zastř̌šující institut a poskytovatel komunitní paliativní péče). Základními oblastmi dotazování byl systém paliativní péče, výzvy při rozvoji paliativní péče, advocacy.

Tato studie má být jedním z příspěvků do procesu hledání a tvoření jednotící vize a strategie paliativní péče v Česku s tím, že s ohledem na rozdílnost prostředí (zejména kulturně-historického a legislativního) popisuje nalezené podobnosti a formuluje doporučení pro přenos zkušeností na úrovni „inspirace“ založené na zjištěných rozdílech. V rámci provedené srovnávací studie jsou porovnávány tři základní oblasti: přístup k paliativní péči, strategické dokumenty a dominantní aktéři na národní úrovni. Studie byla realizována v rámci programu Fakulty humanitních studií Univerzity Karlovy Progres Q20 Kultura a společnost v průběhu srpna až prosince 2019.

\section{Pojetí paliativní péče - TALKING ONE VOICE (Mluvit stejným jazykem)}

Rozvoj paliativní péče v ČR naráží na absenci jednotící vize, respektive na existenci více představ o tom, jak má vypadat péče o člověka s potřebou paliativní péče. Tento obraz není tvořen pouze Ministerstvem zdravotnictví, Ministerstvem práce a sociálních věcí a jednotlivými krajskými úřady, ale z velké části také „zdola“ samotnými poskytovateli a odborníky, kteří se sdružují do asociací, případně do odborných společností. Asociace poskytovatelů paliativní hospicové péče, Česká společnost paliativní péče, Česká společnost hospicové péče a Fórum mobilních hospiců jsou hlavními aktéry rozvoje paliativní péče v ČR, směr rozvoje ovšem není jednotný3.

Irská zkušenost ukazuje, že schopnost „talking one voice“, tzn. že většina aktérů v daném segmentu ví, kam směřuje a čeho chce dosáhnout, umožňuje efektivněji prosazovat zájmy dané skupiny. Respondenti v rozhovorech zmiňovali, že pro sjednocení vize rozvoje paliativní péče v Irsku sloužil dokumentu z roku 2001, ${ }^{4}$ jehož obsah se stal „bibli“ pro poskytovatele a klíčové hráče. Je důležité zmínit, že sjednocujícím prvkem nebyl obsah tohoto dokumentu, ale proces, kterým byl vytvořen. Tento dokument není pouze odborným stanoviskem k rozvoji paliativní péče, ale z velké míry písemným záznamem procesu vyjednávání širokého spektra klíčových aktérů, odborníků, odborných společností a zastřešujících organizací. V komisi, která dokument vypracovala, pracovali zástupci hospiců, nemocnic, onkologů, praktických lékařơ, ministerstev a nadací. Právě i díky široké podpoře, kterou tento dokument měl mezi odborníky, byl následně přijat irským ministerstvem zdravotnictví.

Ve své první části se dokument zaměřuje na obecný popis základních pojmů, úrovní péče a potřeby specializované paliativní péče. Velká část dokumentu je zaměřena na rozvoj specializované paliativní péče. Každá kapitola má jasné, měřitelné a dostatečně specifikované cíle. Např. kapitola 6.3 doporučuje, aby v každém regionu ${ }^{5}$ byla alespoň jedna jednotka lơžkové specializované paliativní péče ${ }^{6}$ (pozn. roli této jednotky plní většinou lůžkové hospice). V kapitole 5.5 je určeno, že by měl existovat alespoň jeden úvazek lékaře s atestací v paliativní medicíně na 160.000 obyvatel,

Ondřej SLÁMA, Aktuální výzvy pro paliativní péči v Evropě a ČR, Senát PČR (sympozium) 2. 10. 2019.

4 (c) NAC, Report of the National Advisory Committee on Palliative Care (on-line), dostupné na: http://hospicefoundation.ie/wpcontent/uploads/2012/07/Report-of-the-National-Advisory-Committee-on-Palliative-Care-2001.pdf, citováno dne 3. 5. 2020.

5 Irsko je rozděleno do osmi tzv. health board areas, které vytváří zdravotní politiku na daném území. Počtem obyvatel odpovídá jednomu kraji v ČR (kolem 700 tis. obyvatel).

6 (c) NAC, Report..., s. 73. 
současně se stanovením minima dvou takových lékařů v jednom regionu. Takto definované cíle umožnily všem zástupcům klíčových organizací prosazovat sdílenou vizi nejen proto, že byly vytvořeny společně, ale také na základě konkrétnosti a dostatečné specifičnosti definovaných doporučení.

\section{Čtyři pilíŕe paliativní péče}

Paliativní péče je v Irsku poskytována ve čtyřech prostředích - v rámci tzv. lůžkových jednotek specializované paliativní péče, $v$ nemocnicích (formou konziliární péče), ve stacionárích specializované paliativní péče a domácím prostředí.

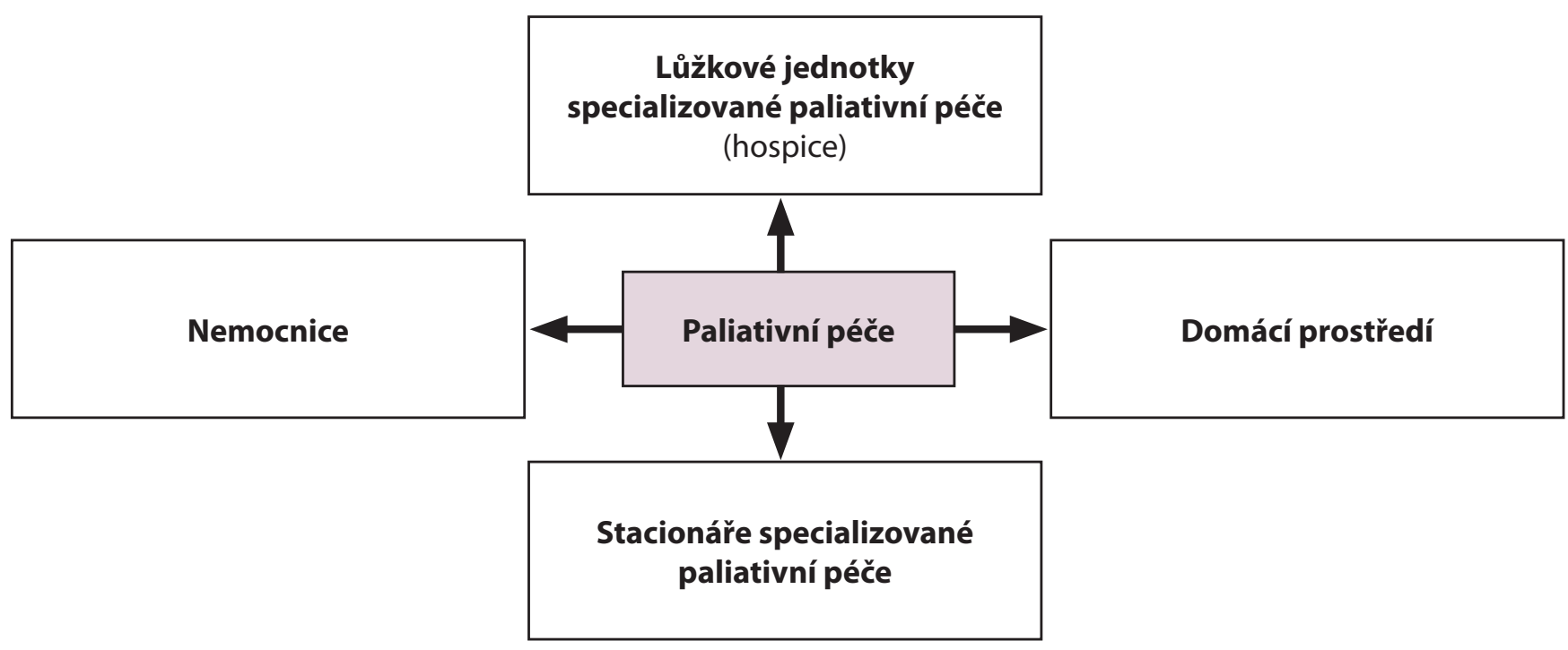

Lůžkové jednotky specializované paliativní péče jsou vnímány jako základní prvek paliativní péče $\mathrm{v}$ každé oblasti, často se jedná o koordinátory péče $\mathrm{v}$ regionu, včetně nemocnic a místních komunit. Fungují jako vzdělávací centrum v oblasti paliativní péče pro ostatní zdravotnické pracovníky v regionu, obvykle poskytují odborné konzultace a také provádějí výzkum v paliativní péči.

V České republice se těmto lůžkovým jednotkám specializované paliativní péče svou formou i obsahem nejvíce blíží lůžkové hospice. Pokrytí těmito zařízeními je v ČR podobné jako v Irsku, ve 14 krajích můžeme najít 15 lůžkových hospiců a dvě paliativní jednotky v nemocnicích.

Paliativní péče $\mathbf{v}$ nemocnici je $\mathrm{v}$ Irsku obvykle zabezpečována multidisciplinárním konziliárním týmem, který poskytuje podporu zdravotnickému personálu. Tým specializované paliativní péče $\mathrm{v}$ Irsku sestává minimálně $\mathrm{z}$ jednoho lékaře $\mathrm{s}$ atestací $\mathrm{v}$ paliativní medicíně, ze specializované sestry, sociálního pracovníka a administrativního pracovníka. Tým specializované paliativní péče pak často ukazuje ostatním zdravotnickým pracovníkům $\mathrm{v}$ zařízení dobrou praxi při práci $s$ vážně nemocnými pacienty. $V$ místě působnosti také často nabízí vzdělání a školení $\mathrm{v}$ paliativní medicíně. Studie ukazují, že zavedení specializovaného týmu paliativní péče do nemocnic vede ke zlepšení kvality péče o pacienty s onemocněním v terminálním stadiu. ${ }^{8}$

V ČR je konziliární paliativní péče relativně novou službou poskytovanou ve zdravotnictví.

8 Regina MCQUILLAN et al., The provision of a palliative care service in a teaching hospital and subsequent evaluation of that service, Palliative Medicine 10(3)/1996; ( ) NAC, Report..., s. 80. 
Počátky jejího fungování byly podpořeny ze zdrojů soukromé nadace, ${ }^{9} \mathrm{v}$ současnosti realizuje Ministerstvo zdravotnictví pilotní projekt „Podpora paliativní péče - zvýšení dostupnosti zdravotních služeb v oblasti paliativní péče v nemocnicích akutní a následné péče “ $s$ cílem podpořit vznik konziliárních paliativních týmů v nemocnicích. Jejich úkolem je, podobně jako v Irsku, formou konzilia, konzultace nebo podpůrné intervence podpořit a usnadnit např. management symptomatické zátěže, formulaci léčebných cílů, komunikaci léčebných alternativ, případně zvládnutí obtížné komunikace s pacientem nebo jeho prŕbuznými (způsobené např̀ diskrepantním očekáváním terapeutických možností). ${ }^{10}$

V obou zemích můžeme vidět, že představy o fungování paliativní péče v nemocnicích se obsahově neliší, můžeme ovšem vysledovat jiný přístup při zavádění těchto změn. V ČR vznikla prozatím krátkodobá podpora omezenému počtu nemocnic, přestože dosud není jasná vize, jak má péče $\mathrm{v}$ budoucnosti vypadat, $\mathrm{v}$ kolika nemocnicích bude podobný tým vytvořen, zda bude jeho fungování hrazeno ze zdrojů zdravotního pojištění. Irský model ukazuje na jiný postup. V první řadě definovali cílový stav - v každé nemocnici poskytuje konziliární služby specializovaný paliativní tým vedený lékařem ${ }^{11}$ a personální obsazení paliativního týmu je dané, jeho členy jsou alespoň jeden paliativní lékař, paliativní sestra, sociální pracovník a administrativní pracovník. ${ }^{12}$

\section{Stacionáře specializované paliativní péče}

Stacionáře poskytující specializovanou paliativní denní péči jsou v Irsku důležitým pilířem v systému péče o pacienty se závažným onemocněním. Jsou určeny pro pacienty, kteří nejsou v terminální fázi nemoci a kteři jsou schopni za službou dojíždět do stacionáře (ten je ve většině př́ípadů napojen na specializované jednotky paliativní péče, tj. na hospice).

Tato forma péče je v ČR prakticky neznámá, ${ }^{13}$ existují dle zákona o sociálních službách centra denních služeb poskytující „ambulantní služby osobám, které mají sniženou soběstačnost $z$ diovodu věku, chronického onemocnění nebo zdravotního postiženi ', ${ }^{14}$ tyto služby ovšem nejsou specializovanou paliativní péćí. K naplnění irské představy by bylo nutné zajistit kromě sociálních také zdravotní služby, a to především dostupnost paliatra, zdravotní sestry, fyzioterapeuta, prípadně dalších profesionálu․ Velkou roli zde mohou hrát také konziliární paliativní týmy, které by v př́ipadě včasné intervence $\mathrm{v}$ nemocničním prostředí mohly pacienty do těchto zařízení doporučit. Tento typ služby může být inspirativní pro již existující české lůžkové hospice.

\section{Domácí prostředí}

V Irsku má praktický lékař odpovědnost za lékařskou péči o své pacienty, spolupracuje s ostatními poskytovateli zdravotní péče, s nemocnicemi a domovy s pečovatelskou službou, stejně jako s poskytovateli komunitní specializované paliativní péče. Klinická odpovědnost za pacienta v Irsku však zůstává na straně praktického lékaře. Tým komunitní specializované paliativní péče doporučuje medikaci a další aspekty péče o pacienta, rozhodnutí o provedení těchto návrhů je ale na uvážení praktického lékaře. Tento model je rozdílný s praxí v ČR, kde poskytovatel mobilní

9 (C) NF Avast, Spolu až do konce (on-line), dostupné na: https://nadacnifond.avast.cz/spolu-az-do-konce, citováno dne 3. 5. 2020.

10 ๑ MZČR, Výzva k předkládání žádostí o dotaci v rámci Programu Podpory paliativní péče - zvýšení dostupnosti zdravotních služeb v oblasti paliativní péče v nemocnicích akutní a následné péče, 2019 (on-line), dostupné na: http://www.mzcr.cz/Unie/obsah/podporapaliativni-pece-nemocnicni_3984_8.html, citováno dne 31.5.2020.

11 (C) NAC, Report..., s. 81.

12 (c) NAC, Report..., s. 82. Složení týmu je obdobné v Pilotním projektu MZČR a irském NAC.

13 S výjimkou dětského hospicového stacionáře, který provozuje MH Ondrášek, viz https://www.mhondrasek.cz/cz/detsky-hospicovystacionar.

14 Zákon č. 108/2006 Sb., o sociálních službách, \$45 zákona. 
specializované paliativní péče přebírá pacienty do péče (v českém kontextu se bavíme o tzv. domácí hospitalizaci). Český model zjednodušuje práci poskytovateli $\mathrm{MSPP}^{15}$, který je odpovědný za kvalitu služeb a nemusí spoléhat na praktického lékaře, zároveň ovšem tento př́stup vytváŕí pnutí mezi MSPP a praktickými lékaři, kteří mají často pocit, že jim poskytovatel MSPP intervenuje $\mathrm{v}$ jejich prostředí, u pacienta, kterého mnohdy doprovází celý život. Z hlediska implementace komunitní paliativní péče bychom mohli předpokládat, že irský model vyžaduje vyšší míru komunikace mezi subjekty, zároveň ovšem zvyšuje kompetence praktických lékařu (ti mohou v př́ipadě blízké spolupráce s MSPP zvyšovat své kompetence $\mathrm{v}$ péči o těžce nemocné pacienty). Tento model snižuje nebezpečí vzniku konfliktu mezi MSPP a praktickými lékaři z důvodu přebírání pacientů do výhradní péče MSPP.

V Irsku, obdobně jako v ČR, jsou služby komunitní specializované péče (resp. MSPP) poskytovány často, nikoli však výlučně, skrze týmy, které vznikly při existujících jednotkách specializované paliativní péče (resp. lůžkových hospicích).

Organizace specializované paliativní péče $\mathrm{v}$ Irsku stojí především na konziliárních paliativních týmech při nemocnicích a hospicových centrech, která poskytují souběžně lůžkovou, ambulantní i terénní péči („péči v komunitě“). Spolupráci mezi těmito službami v řadě př́ípadů usnadňuje souběžné angažmá lékaře - paliatra ve všech formách služby paliativní péče. Irský model ukazuje, že specializovaná paliativní péče je primárně poskytována ve dvou typech zařízení - v lůžkovém hospici poskytujícím služby paliativního stacionáře a komunitní paliativní péče a v nemocnicích s ustanoveným konziliárním paliativním týmem. Nastavení spolupráce mezi těmito aktéry je dle respondentů důležitým prvkem pro efektivní koordinaci péče o pacienty. V Irsku je vzájemná spolupráce zpravidla podpořena personálně (paliatři pracující v nemocnicích pracují i v lůžkových hospicích) a prostorově (lůžkové hospice bývají vybudovány na dohled nemocnici).

\section{Národní klinický program paliativní péče}

V roce 2010 byl v Irsku vytvořen Národní klinický program paliativní péče, jehož cílem je zajistit, aby pacienti s život limitujícím onemocněním a jejich rodiny měli snadný př́stup $\mathrm{k}$ paliativní péči odpovídající jejich potřebám. Program koordinuje národní klinický leader, národní leader $\mathrm{v}$ ošetřovatelství a vedoucí programu, kteří spolupracují na zajištění plnění cílů programu. Kromě této výkonné skupiny je zároveň ustanovena multiprofesní pracovní skupina zajištující podporu výkonnému výboru při implementaci programu.

Jednotlivé operativní cíle jsou určeny ve výše zmíněném dokumentu Report of the National Advisory Committee on Palliative Care. ${ }^{16}$

Pokud bychom měli zrekapitulovat vývoj implementace paliativní péče do zdravotnického systému v Irsku, vidíme dva základní milníky:

1. prríprava dokumentu popisujícího žádoucí cílový stav (Report of the National Advisory Committee on Palliative Care), který byl následně přijat ministerstvem zdravotnictví (rok 2001);

15 Mobilní specializovaná paliativní péče (MSPP) je formou poskytování specializované ambulantní paliativní péče v domácím nebo náhradním sociálním prostředí v režimu nepřetržité dostupnosti lékařské a ošetřovatelské péče. Tento organizační model má charakter tzv. domácí hospitalizace, viz https://www.paliativnimedicina.cz/stanovisko-k-otazce-ambulantni-a-mobilni-specializovanepaliativni-pece/, citováno dne 3. 5. 2020.

16 C HSE, Palliative Care, (Three year development framework - 2017-2019), (on-line) dostupné na: https://www.hse.ie/eng/about/who/ cspd/ncps/palliative-care/resources/, citováno dne 31. 5. 2020. 
2. etablování Národního klinického programu paliativní péče, vytvoření pozic národní klinický leader, národní leader v ošetřovatelství a vedoucí programu (rok 2010) realizujících program.

V ČR v minulosti vznikla z iniciativy České společnosti paliativní péče Strategie rozvoje paliativní péće v České republice na období 2011-2015, poté také aktualizovaná verze pro roky 2015-2020, oba návrhy byly vládou ČR odmítnuty jako zbytečné. ${ }^{17}$

$\mathrm{V}$ posledních letech začaly vznikat strategické dokumenty na krajských úrovních (např. Jihočeský kraj $^{18}$, Kraj Vysočina ${ }^{19}$, Jihomoravský kraj ${ }^{20}$, Magistrát hlavního města Prahy ${ }^{21}$ ) ukazující zájem o systematický rozvoj paliativní péče $\mathrm{v}$ regionech.

Na celostátní úrovni můžeme za průlomový okamžik označit podepsání memoranda Ministerstva zdravotnictví ČR, zdravotních pojištoven a České společnosti paliativní medicíny ČLS JEP o spolupráci na systematickém rozvoji paliativní péče v ČR. Dokument nepopisuje konkrétní operativní cíle rozvoje paliativní péče v ČR, ale identifikuje následující oblasti spolupráce:

- pilotní ověření a analýza provozů specializované paliativní péče poskytované v nemocnicích akutní a následné péče;

- pilotní ověření a analýza vykázané domácí specializované paliativní péče;

- návrh indikačních kritérií pro paliativní péči u relevantních forem paliativní péče;

- kvantifikace pacientské populace splňující indikační kritéria pro paliativní péči;

- návrh optimální a udržitelné kapacity sítě poskytovatelů specializované paliativní péče;

- analytické zpracování dostupných dat a návrh optimální a udržitelné kapacity sítě poskytovatelů paliativní péče o pacienty ve věku $0-18$ let;

- př́ípadná doporučení změn legislativního charakteru, která by na základě těchto analytických materiálů byla identifikována. ${ }^{22}$

Role koordinátora této spolupráce přináleží dle memoranda ČSPM.

Srovnání irského a českého systému zavádění paliativní péče do systému ukazuje principiálně odlišný př́stup. V Irsku odborníci vytvořili sdílenou vizi (představu budoucího stavu), která byla následně realizována státem, viz následující obrázek:

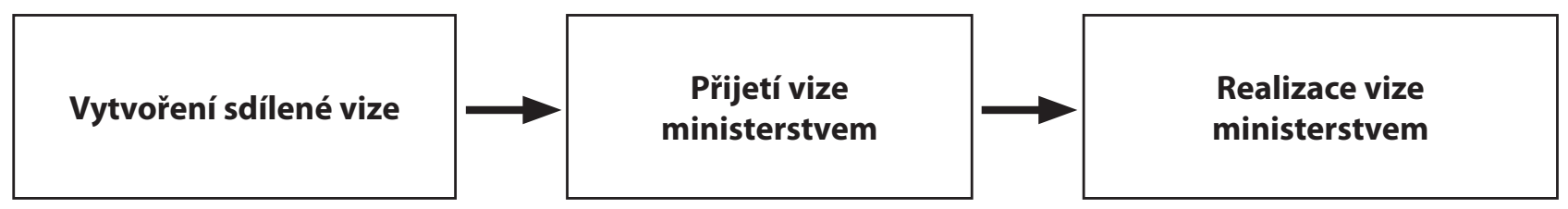

17 C ČSPM, Strategie rozvoje paliativní medicíny a péče v České republice v letech 2015-2020, Brno, 2015 (on-line), dostupné na: https:// www.paliativnimedicina.cz/projekty/nf-avast/strategie-rozvoje-paliativni-mediciny-a-pece-v-ceske-republice-v-letech-2015-2020/, citováno dne 30.5.2020.

18 C) Jihočeský kraj, Koncepce paliativní péče v Jihočeském kraji na období do roku 2023 (on-line), dostupné na: https://www. kraj-jihocesky.cz/sites/default/files//ku_usneseni/Zastupitelstvo/2018-09-06/Navrhy/261-ZK-18_Koncepce_paliativni_pece_v_ Jihoceskem_kraji_na_obdobi_do_roku_202.pdf, citováno dne 3.5. 2020.

19 C Kraj Vysočina, Strategie paliativní péče v Kraji Vysočina na období do roku 2020 (on-line), dostupné na: https://www.kr-vysocina. cz/paliativni-pece/ds-303865/p1=92885, citováno dne 3. 5. 2020.

20 (c) Jihomoravský kraj, Koncepce paliativní péče v Jihomoravském kraji (on-line), dostupné na: https://www.paliatr-vysocina.cz/wpcontent/uploads/2019/10/paliativni_pece_krajske-setkani.pdf, citováno dne 3. 5. 2020.

21 () MHMP, Analýza paliativní péče v hlavním městě Praha (on-line), dostupné na: https://paliativnicentrum.cz/projekty/analyzapaliativni-pece-v-hlavnim-meste-praha, citováno dne 3. 5. 2020.

22 ○ MZČR, Memorandum o spolupráci na systematickém rozvoji paliativní péče (on-line), dostupné na: https://www. paliativnimedicina.cz/na-mz-bylo-podepsano-memorandum-o-spolupraci-na-systematickem-rozvoji-paliativni-pece/, citováno dne 3. 5. 2020. 
V ČR se využívá spíše model pilotování nových služeb, sběr dat a případné zajištění financování z prostředků veřejného zdravotního pojištění. Koordinační a odbornou roli nese Česká společnost paliativní medicíny.

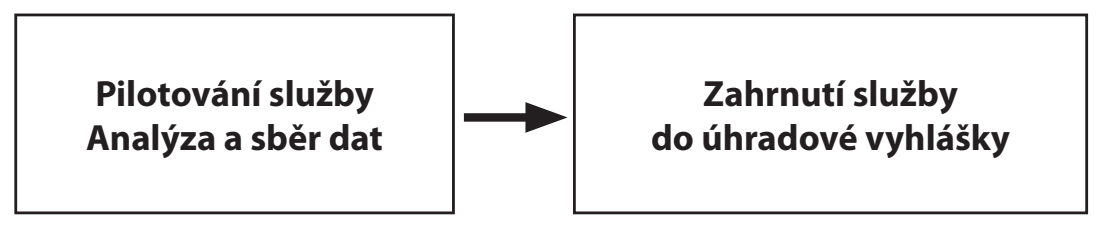

Český model může být vnímán jako velmi opatrný, minimalizující riziko pro zdravotní pojištovny a Ministerstvo zdravotnictví, kteři se pilotováním služeb potřebují ujistit, že i v českém prostředí (ačkoliv zahraniční zkušenost toto již prokázala) mohou paliativní služby prokázat svůj př́nos pro pacienty a nákladovou efektivitu. Tento př́stup přináší ale i velkou nejistotu pro zúčastněné subjekty, není zřejmé, jakým směrem bude v budoucnu směřovat rozvoj paliativní péče v ČR. Výsledkem pilotních projektů sice může být nastavení financování dané služby, ale to není poskytovatelům těchto pilotních služeb zaručeno.

Je také otázkou, zda mandát ČSPM při koordinaci rozvoje paliativní péče není př́liš slabý, zda by tedy dle irského modelu neměl vzniknout výkonný výbor při MZČR, který by odpovídal za realizaci ucelené koncepce, a ta by následně dávala poskytovatelům určitou záruku stabilního vývoje.

\section{Přístup k paliativní péči - Odstupňovaná paliativní péče, přístup vs. výkon}

Evropská asociace poskytovatelů paliativní péče využívá ke specifikaci paliativní péče koncept tzv. „odstupňované hospicové a paliativní péče “. 23 Při srovnání pojetí paliativní péče ve strategických dokumentech mezi ČR a Irskem je zřejmý jeden podstatný rozdíl. V ČR převažuje pojetí paliativní péče jako dvoustupňové, tj. obecná paliativní péče a specializovaná paliativní péče s tím, že $\mathrm{k}$ jednotlivým úrovním (a mezi-úrovním) jsou přriřazeny ilustrativní př́klady aktérů ${ }^{24}$. Irsko využívá koncept odstupňování paliativní péče do tří stupňủ, který je v současné době užíván i Evropskou asociací paliativní péče (EAPC) ${ }^{25}$ a to v členění na paliativní prístup, obecnou paliativní péči a specializovanou paliativní péči. ${ }^{26}$ Důvodem rozhodnutí pro užívání dvoustupňového modelu, který zmiňuje i EAPC, může být „jednoduchost“, která byla z pohledu ČSPM ČLS JEP ${ }^{27}$ cenná ve fázi etablování paliativní péče, zejm. v systému zdravotní péče a zdravotních služeb. Tři úrovně paliativní péče dle doporučení EAPC definují tyto úrovně následovně:

- první úroveň - paliativní př́stup: principy paliativní péče mají být vhodně aplikovány všemi zdravotnickými profesionály;

- druhá úroveň - obecná paliativní péče: část pacientů a rodin bude mít prospěch z odbornosti

23 Původně schéma odstupňované paliativní péče používá organizace Hospiz Österreich od roku 2004 - viz: @ ÖSTERREICH, Gesundheit. Abgestufte Hospiz-und Palliativversorgung für Erwachsene. Aufl. Gesundheit Österreich, Wien (on-line), dostupné na: https://www.hospiz.at/wordpress/wp-content/uploads/2016/05/broschuere_hospiz-_und_palliativversorgung_1_12_2014.pdf, citováno dne 30.1.2020.

24 Dvoustupňový koncept paliativní péče je využit ve Věstníku Ministerstva zdravotnictví ČR č. 14/2017 v rámci Metodického pokynu Ministerstva zdravotnictví ČR k poskytování mobilní specializované paliativní péče, s. 23-24.

25 @ Lukáš RADBRUCH, Sheila PAYNE, White Paper on standards and norms for hospice and palliative care in Europe: part 1, European journal of palliative care (on-line), dostupné na: https://www.eapcnet.eu/Portals/0/adam/Content/ LmgAajW9M0Os7VYZs0ZXCQ/Text/White\%20Paper\%20on\%20standards\%20and\%20norms\%20for\%20hospice\%20and\%20 palliative\%20care\%20in\%20Europe.pdf, citováno dne 30. 1. 2020.

27 Česká společnost paliativní medicíny České lékařské společnosti Jana Evangelisty Purkyně. 
zdravotnických profesionálů, kteří se sice paliativní péči nevěnují na plný úvazek, mají však dodatečný výcvik a zkušenosti v oblasti paliativní péče;

- třetí úroveň - specializovaná paliativní péče: služby specializované paliativní péče, jejichž hlavní činnost je omezena na poskytování paliativní péče.

Tato struktura se promítá do nároků na kompetence odborníků v různých pomáhajících profesích, současně i formuje očekávání od služeb a legitimní nároky na různé aktéry. Dvoustupňový model nabízí přehlednou strukturu pro zdravotnické profese, zejména lékaře. Pro další profese multidisciplinárního týmu nabízí třístupňový model zřetelnější prostor k uplatnění, např. i mimo zdravotnické obory - v sociálních službách apod. ${ }^{28}$

Výhody schématického rozdělení se projevují v oblasti kompetencí. Současně se ukazuje, že důraz na paliativní přístup zvyšuje pravděpodobnost včasného zapojení paliativní péče (důraz na kompetence SP v dovednosti využít profesionály obecné a specializované PP jako zdroj podpory pro pečující v první úrovni - tj. konzilium, zaškolení, rada aj.).

Irský systém akcentuje konziliární pojetí specializované paliativní péče. Toto pojetí předpokládá, že jednou $\mathrm{z}$ kompetencí profesionálů působících na úrovni paliativního přístupu, příp. obecné paliativní péče je, že „berou v úvahu potenciální úlohu specializovaných služeb paliativní péče při podpoře zaměstnanců $\mathrm{v}$ jiných organizacích, aby zajistili prrístup $\mathrm{k}$ paliativní péči (na úrovni paliativního př́stupu - pozn. autora) osobám s život ohrožujícím onemocněním. “29 Tento koncept podporuje dostupnost paliativní péče a zároveň posiluje efektivní využívání kapacit specializované paliativní péče. Takové pojetí předchází vnímání „ostrých rozhraní, na kterých dochází k „předávání pacienta/klienta“ do péče jiného profesionála, resp. subjektu. Místo toho je do spektra podpůrných a pomáhajících služeb a profesionálů „přizván“ další prvek. Praxe v ČR prochází procesem vymezování jednotlivých profesí, služeb a forem mezi sebou navzájem. Tento proces může ovšem zajištěním vyšší dostupnosti specializované paliativní péče paradoxně zapříčinit i obtížnější dostupnost běžné zdravotní péče. ${ }^{30}$ Zkušenost poskytovatelů paliativní péče na úrovni paliativního př́stupu ${ }^{31}$ potvrzuje, že vhodné angažování specializované paliativní péče v režimu konziliárním či v režimu sdílené péče může být vysoce efektivním způsobem zajištění dostupnosti paliativní péče široké skupině potenciálních klientů/pacientů. Současně může přispět k prosazení konceptu časné paliativní péče. ${ }^{32}$

\section{Výzkum, organizování, advocacy ${ }^{33}$}

Paliativní péče je ve své podstatě multidisciplinární, celostní přístup k potřebám člověka se promítá v nároku na koordinaci a spolupráci širokého spektra pomáhajících profesí i pomáhajících

28 Karolína HRDÁ, Matěj LEJSAL et al., Paliativní péče v rezidenčních službách, Tábor, Asociace poskytovatelů sociálních služeb České republiky, 2020, s. 88.

29 ๑ Karen RYAN et al., Palliative care competence framework (on-line), dostupné na: https://aiihpc.org/our_work/education/ competence-framework/, s. 74, překlad autora, citováno dne 20.12. 2019.

30 Současný systém financování specializované paliativní péče předpokládá, že mobilní tým specializované paliativní péče převezme odpovědnost za veškerou zdravotní péči (resp. veškerá péče jde „na vrub“ mobilního týmu). Tento stav může být kontraproduktivní nap̌r. u geriatrických pacientů, u kterých může být vedle paliativní péče indikována i péče kurativní. Na toto riziko upozorňuje ve svých vystoupeních např. MUDr. Zdeněk Kalvach.

31 Např́klad zkušenost služby domova pro seniory Sue Ryder, @ Domov Sue Ryder, z. ú. (on-line), dostupné na: http://www.sue-ryder.cz, citováno dne 31.5. 2020.

32 Ondřej KOPECKÝ et al., Úloha paliativní medicíny u akutních stavů, Vnitřní lékařství 6/2019, s. 449.

33 Advokace (advocacy) je činnost jednotlivce nebo skupiny, jejímž cílem je ovlivňovat rozhodnutí v rámci politických, ekonomických a sociálních systémů a institucí. 
laiků. To, co v praxi přináší pozitivní efekt pro kvalitu života klienta/pacienta, vznáší vysoké nároky na koordinaci dalších souvisejících procesů - výzkum, organizování poskytovatelů paliativní péče a správu a úsilí o rozvoj systémů zdravotní a sociální péče a zabezpečení (advocacy). Koordinovanost těchto procesů ve výsledku ovlivní reálnou dostupnost paliativní péče pro běžného člověka. Pro srovnání prostředí ČR a Irska se studie zaměřila na institucionalizovanou podobu koordinace, tj. na identifikaci subjektů, které jsou dle strategických dokumentů a výpovědí respondentů aktivní $\mathrm{v}$ plošné koordinaci a facilitaci procesu výzkumu, organizování profesionálů v paliativní péči a správy a rozvoje systémů.

\section{Výzkum}

Témata výzkumu v paliativní péči v Irsku byly vedeny oborově (po profesní linii), obdobně jako v ČR. Podstatný impuls ke změně přinesla srovnávací studie Sonji Mcllfatrick a Tary Murphy publikovaná v roce $2013^{34}$. V návaznosti na doloženou absenci mezioborového výzkumu většího rozsahu byl založen All Ireland Institute of Hospice and Palliative Care (Celoirský institut hospicové a paliativní péče, AIIHPC).$^{35}$ Institut reagoval na potřebu mezioborové spolupráce při výzkumu a na potřebu meziorganizační a mezisektorové spolupráce. Plní roli facilitátora pro rozvoj paliativní a hospicové péče v oblasti výzkumu, vytváří prostor pro propojení akademikủ a vzdělavatelů, klinických odborníků, pracovníků veřejné správy a klientů/pacientů a jejich blízkých. Pomáhá vytvářet prostor pro akademický i aplikovaný výzkum a podporuje využití poznatků v běžné praxi. Možnou ukázkou výsledků práce je dokument Palliative Care Competence Framework (Rámec kompetencí v paliativní péči) ${ }^{36}$ definující nároky na kompetence pracovníků širokého spektra profesí obvykle zapojovaných do poskytování paliativní péče. V podmínkách ČR podobný subjekt dosud chybí. Iniciativu podobné povahy vyvíjí Centrum paliativní péče $(\mathrm{CPP})$. $^{37}$ Podstatný rozdíl mezi AIIHPC a CPP je jednak v rozsahu aktivit, především však ve způsobu ř́izení obou organizací (governance). Do ř́izení AIIHPC jsou zapojeni zástupci všech partnerských organizací (univerzit, poskytovatelů paliativní péče, nemocnic, odborných společností apod.). CPP je mladou ${ }^{38}$ neziskovou organizací, která má základní rídící strukturu vycházející z právní formy zapsaného ústavu. ${ }^{39}$

\section{Organizování profesionálů}

Paliativní péče stojí na multidisciplinární spolupráci. Bílá kniha EAPC explicitně říká, že: „služby specializované paliativní péče vyžadují týmový přístup, kombinující tým sestavený z více profesí $s$ mezioborovým způsobem spolupráce. ${ }^{\text {"40 }}$ Vhodný způsob organizování týmů, systém vzdělávání, způsob řízení organizací, které poskytují služby specializované paliativní péče, je dán mj. formou poskytování služby. Paliativní tým v prostředí nemocnice se zaměřuje na jiné faktory než tým lůžkového hospice či terénní tým. Vedle vnitřního prostředí organizací a týmů působících

34 C Sonja MCILFATRICK, Tara MURPHY, Palliative care research on the island of Ireland over the last decade: a systematic review and thematic analysis of peer reviewed publications. BMC Palliative Care (on-line), dostupné na: https://link.springer.com/ article/10.1186/1472-684X-12-33, citováno dne 30. 1. 2020. 
v oblasti specializované paliativní péče hraje podstatnou roli vnější prostředí (legislativa, systémy financování, systém vzdělávání budoucích odborníků apod.). Vhodným prostředkem pro rozvoj organizací, dobré praxe a pro účast na formování vnějšího prostředí je oborová spolupráce v podobě zastřešující sítě.

V Irsku je takovým subjektem Irish Association for Palliative Care (Irská asociace pro paliativní péči) ${ }^{41}$ která byla založena $\mathrm{v}$ roce 1993 a sdružuje profesionály působící v oblasti paliativní péče a je kolektivním reprezentantem zájmů a potřeb členů na národní a mezinárodní úrovni, v rámci této asociace působí řada stálých či ad hoc pracovních skupin a výborů. Jednotícím prvkem je téma paliativní péče, organizace doplňuje činnost dalších profesních skupin a asociací.

V prostředí České republiky je situace méně přehledná. Agenda je rozptýlena mezi několik subjektů - Česká společnost paliativní medicíny České lékařské společnosti Jana Evangelisty Purkyně $(\check{C} S P M)^{42}$ založená v roce 2008 a její odborné sekce a pracovní skupiny, které sdružují profesionály v paliativní péči. Dalšími subjekty jsou organizace, které sdružují především organizace poskytující služby paliativní péče, a to Asociace poskytovatelů hospicové paliativní péče založená v roce 2005 a Fórum mobilních hospiců založené v roce 2017. Vnitřní nejednotnost se projevuje jak v rámci České republiky, tak v rámci spolupráce mezinárodní. ${ }^{43}$

\section{Advocacy}

Rozvoj paliativní péče je úzce svázán s politikou státu v oblasti sociálního zabezpečení a služeb, zdraví a vzdělávání. Jednotlivé subjekty v celém spektru paliativní péče často vyvíjejí úsilí k ovlivnění této politiky na místní úrovni, některé i v celostátním měřítku, některé vyvíjejí iniciativu ad hoc, jiné dlouhodobě. Komplexní zmapování ustavení paliativní péče v systému služeb a jeho srovnání v Irsku a ČR přesahuje rámec tohoto textu. V současnosti se prostředí liší především směrem vyvíjených iniciativ. Zatímco v Irsku je možné vysledovat směr „shora dolü“ (top-down), v ČR převažují iniciativy „zdola nahoru“ (bottom-up). Již zmiňovaný Report of the National Advisory Committee on Palliative Care ${ }^{44} \mathrm{v}$ úvodní části zdůrazňuje př́nos občanské společnosti k rozvoji paliativní péče, na který další úsilí navazuje. Nejde pouze o jakési dějinné zpoždění, není tedy jen otázka času, kdy politika státu dosud vytvořené instituty, nástroje a „dobrou praxi“ akceptuje jako stabilní součást systému a bude dále podporovat rozvoj existujících a nových nástrojů, prvků a metod. Jde mimo jiné o zásadně odlišné právní systémy Irska a ČR ${ }^{45}$ které mají př́mý dopad na úspěšnost „advocacy“ strategií. Přesto je možné se i zde inspirovat, zejména v oblasti ne-legislativních cílů a postupů. Za úspěšné „advocacy“ strategie v oblasti paliativní péče v ČR byly dosud považovány iniciativy, které iniciovaly změnu legislativního prostředí (například uzákonění hospicové péče v roce 2017) ${ }^{46}$ Dílčí legislativní změny bez širších systémových souvislostí a bez

41 (C) Irish Association for Palliative Care (on-line), dostupné na: http://www.iapc.ie/about-us/.

42 C) Česká společnost paliativní medicíny (on-line), dostupné na: https://www.paliativnimedicina.cz/cspm/.

43 Této problematice se věnoval mj. př́spěvek MUDr. Ondřeje Slámy v rámci sympozia Aktuální výzvy pro paliativní péči v Evropě a ČR, které pořádalo Centrum paliativní péče dne 2. 10. 2019 v Praze.

44 HSE, Palliative..

45 Velmi zjednodušeně je možné říci, že Irsko využívá tzv. anglo-americký systém práva, které mj. využívá tzv. common-law. To do právního řádu vnáší princip využití precedentu a zvyklosti při rozhodování. ČR funguje v režimu tzv. kontinentálního práva, ve kterém je striktně odděleno právo veřejné a soukromé a které současně předpokládá psanou podobu práva. Přehledné srovnání právních systémů nabízí (C) Václava LUKEŠOVÁ, Právní systémy současného světa se zaměřením na srovnání kontinentálního a angloamerického právního systému (on-line), dostupné on-line: https://is.cuni.cz/webapps/zzp/download/150024372, citováno dne 1. 6. 2020. 
vazby na jednotící vizi mohou vyvolávat obavy či odpor jiné části odborné veřejnosti (srov. rozporující stanovisko $\mathrm{k}$ výše zmíněné legislativní změně zpracované pro ČSPM ČLS JEP) ${ }^{47} \mathrm{~V}$ ČR se zatím nepodařilo získat pro téma paliativní péče klíčové aktéry tvořící dlouhodobější strategii v oblasti zdraví a sociální bezpečnosti a vytvořit prostředí pro systematickou práci založenou na datech, vyjednávání a zapojování klíčových aktérů na mikro, mezo i makroúrovni. V návrhu strategického dokumentu Zdraví $2030^{48}$ je paliativní péče zmíněna velmi omezeně, v zásadně především jako sada opatření (druhy služeb, kapacity apod.). Změna podmínek pro rozvoj paliativní péče není pouze $\mathrm{v}$ jejich kvantitativním posílení, legislativní úpravě či objemu finančních prostředků. Explicitně je toto vyjádřil Dr. Tony $\mathrm{O}$ 'Brien, předseda Národního poradního výboru: „...V nadcházejících letech nebude úspěch nebo neúspěch této zprávy posuzován pouze podle počtu nebo rozmanitosti našich specializovaných programů paliativní péče, ani podle souboru předem stanovených statistik dokumentujících naše činnosti. Úspěch této zprávy bude posuzován podle toho, do jaké míry se všichni naučíme rozpoznat a reagovat na složité a nároky nesoucí potřeby paliativních pacientů a jejich rodin (blizkých). “49 Lze tedy usuzovat, že bez změny postojů k procesu „advocacy“, bez sdílené vize a jasných cílů se nejen nepodaří využít synergie k prosazení změn, ale úsilí části odborného spektra může být naopak oslabováno či vyčerpáváno úsilím jiné části.

O úspěchu v rámci „advocacy“ rozhoduje mj. i zapojení potřebných zdrojů - sítí kontaktů, lidí, informací a financí. Při sledování původu řady aktuálních strategických iniciativ a systémových dokumentů bylo v Irsku i v ČR možné vysledovat subjekt, za jehož podpory řada z nich vznikala. V Irsku se jedná o Irish Hospice Foundation (Irská hospicová nadace), ${ }^{50}$ v prostředí ČR je za podobný subjekt možné označit Nadační fond AVAST. ${ }^{51}$ Pro oba subjekty je společným rysem to, že sami nejsou poskytovateli paliativní péče, ani se nejedná o profesní sdružení. Primárním nástrojem vlivu je v obou př́padech finanční podpora iniciativ s potenciálem významného dopadu na rozvoj paliativní péče a změny veřejných politik v návaznosti na relevantní poznatky, výsledky výzkumů, pilotních ověření. Irish Hospice Foundation je subjekt zřízený právě za tímto účelem, program je spravován zástupci odborné veřejnosti. Jedná se o nadaci, tj. subjekt určený $\mathrm{k}$ „trvalé službě společensky nebo hospodářsky užitečnému účelu“, 52 přičemž účel byl specifikován zakladatelem. Irish Hospice Foundation tak podporuje projekty na základě širšího konsenzu odborné veřejnosti. Nadační fond AVAST je firemním nadačním fondem, jehož správa je v rukách zakládající korporace prostřednictvím jejího práva jmenovat správní radu jakožto statutární orgán fondu. Podstatný rozdíl je i ve způsobu získávání finančních zdrojů, které tyto subjekty následně distribuují. Irish Hospice Foundation vedle výnosů z nadačního jmění aktivně získává prostředky ve veřejném prostoru. Přispívá tím $\mathrm{k}$ posílení povědomí a zájmu o téma paliativní péče, $\mathrm{v}$ některých případech však současně konkuruje v procesu získávání dárců dalším subjektům (např. poskytovatelům paliativní péče). Nadační fond AVAST rozděluje finanční zdroje věnované zakládající korporací. Z pohledu stavu rozvoje paliativní péče v ČR (nově vznikající poskytovatelé, nedostatečná legislativní zakotvenost služeb paliativní péče apod.) lze říci, že dosavadní forma

47 Stanovisko zpracované advokátkou MUDr. Mgr. Dagmar Záleskou problematizuje legislativní změnu, plný text stanoviska je k dispozici (on-line), dostupné na: https://www.cestadomu.cz/sites/default/files/stanovisko_k_ss_44a.pdf, citováno dne 3. 5. 2020.

48 ○) Ministerstvo zdravotnictví ČR, Zdraví 2030 - Strategický rámec rozvoje péče o zdraví v České republice do roku 2030 (on-line), dostupné na: https://zdravi2030.mzcr.cz/zdravi-2030-strategicky-ramec.pdf, citováno dne 6. 5. 2020 - poznámka autora: Paliativní péče se vyskytuje na str. $36, \mathrm{v}$ kapitole věnované vědě zcela absentuje.

49 (c) NAC, Report..., s. 5.

50 () Irish Hospice Foundation - https://hospicefoundation.ie.

51 (C) Nadační fond AVAST - https://nadacnifond.avast.cz/index.

52 Zákon č. 89/2012 Sb., občanský zákoník, \$ 306. 
i objem podpory představuje mimořádně významný impuls k rozvoji celého oboru v ČR. Oba zmíněné subjekty přes uvedené rozdíly využívají vysoce participativní techniky a postupy $k$ identifikaci témat vhodných $\mathrm{k}$ podpoře. ${ }^{53}$

\section{Shrnutí:}

Při srovnání systémů ČR a Irska je možné najít řadu paralel a současně načerpat bohatou inspiraci. $Z$ řady důvodů (např. rozdílné právní prostř̌edí) není možné jednotlivé kroky pouze kopírovat. V mnoha ohledech je možné se inspirovat. Samo srovnání a úsilí o porozumění popsaným rozdílům může posloužit pro rozvoj celého oboru. Různé úhly pohledů při srovnávání systémů zachycuje vložená tabulka.

\begin{tabular}{|c|c|c|}
\hline & IRSKO & ČESKO \\
\hline $\begin{array}{l}\text { Míra sjednocení vize } \\
\text { („talking one voice") }\end{array}$ & $\begin{array}{l}\text { Report of the National } \\
\text { Advisory Committee on } \\
\text { Palliative Care, 2001 } \\
\text { Palliative Care Services - } \\
\text { Three Year Development } \\
\text { Framework 2017-2019 } \\
\text { - odkazuje na předchozí } \\
\text { dokument } \\
\text { The Palliative Care Glo- } \\
\text { ssary of Terms } \\
\text { Palliative Care Needst } \\
\text { Assessment Guidance }^{2}\end{array}$ & $\begin{array}{l}\text { Koncepce paliativní péče v ČR. Pracovní materiál } \\
\text { k odborné a veřejné diskusi, } 2004 \text { (ČSPM) } \\
\text { Národní program paliativní péče, } 2015 \text { (ČSPM) } \\
\text { Paliativní péče v České Republice } 2016 \text { - Situační } \\
\text { analýza (ČSPM) } \\
\text { Koncepce hospicové péče, } 2017 \text { (APHPP) } \\
\text { Strategie paliativní péče v Kraji Vysočina na období } \\
\text { do roku 2020, } 2017 \\
\text { Koncepce podpory rozvoje paliativní péče } \\
\text { v Olomouckém kraji, } 2018 \\
\text { Koncepce paliativní péče v Jihočeském kraji na } \\
\text { období do roku 2023, } 2018 \\
\text { Koncepce rozvoje paliativní péče v Praze, } 2020 \\
\text { Koncepce paliativní péče v Moravskoslezském kraji } \\
\text { 2020-2025, } 2020\end{array}$ \\
\hline $\begin{array}{l}\text { Přístup k rozvoji palia- } \\
\text { tivní péče }\end{array}$ & $\begin{array}{l}\text { Od sdílené vize přes cíle } \\
\text { k realizaci: Sdílená vize } \\
\text { - cíle - strategie - im- } \\
\text { plementace systémových } \\
\text { nástrojů - rozvoj služeb } \\
\text { a prvků systému }\end{array}$ & $\begin{array}{l}\text { Od dílčích vizí a praxe } \mathbf{k} \text { legislativě: Dílčí vize - } \\
\text { experimenty a piloty - včleňování do systému }\end{array}$ \\
\hline $\begin{array}{l}\text { Organizace specializova- } \\
\text { né paliativní péče }\end{array}$ & $\begin{array}{l}\text { Nemocnice } \\
\text { Lǔžková zařízení speci- } \\
\text { alizované paliativní péče } \\
\text { (hospice) } \\
\text { Péče v komunitě - Mobil- } \\
\text { ní specializovaná palia- } \\
\text { tivní péče, Ambulantní } \\
\text { paliativní péče (stacioná- } \\
\text { re, ambulance) }\end{array}$ & $\begin{array}{l}\text { Nemocnice } \\
\text { Lǔžkové hospice } \\
\text { Mobilní specializované týmy paliativní péče } \\
\text { Ambulance paliativní péče }\end{array}$ \\
\hline
\end{tabular}

53 Za uplynulých 5 let NF AVAST investoval do podpory rozvoje paliativní péče v ČR přes 150 mil. Kč. Při př́pravě programů i při výběru podpořených projektů aktivit využivá ve vysoké míře participativní techniky. 


\begin{tabular}{|c|c|c|}
\hline $\begin{array}{l}\text { Vnitřní členění paliativní } \\
\text { péče }\end{array}$ & $\begin{array}{l}\text { Tříúrovňový model (pa- } \\
\text { liativní přístup - obecná } \\
\text { paliativní péče - specia- } \\
\text { lizovaná paliativní péče) }\end{array}$ & $\begin{array}{l}\text { Dvojúrovňový model (obecná paliativní péče - } \\
\text { specializovaná paliativní péče) }\end{array}$ \\
\hline $\begin{array}{l}\text { Př́stup k roli specializo- } \\
\text { vané paliativní péče }\end{array}$ & $\begin{array}{l}\text { konziliární (specializo- } \\
\text { vaná paliativní péče se } \\
\text { přidává v konziliární roli } \\
\text { k běžným službám, řeší } \\
\text { to, co není v možnostech } \\
\text { poskytovatelů obecné } \\
\text { paliativní péče) }\end{array}$ & $\begin{array}{l}\text { kontrolně-výkonový (specializovaná paliativní } \\
\text { péče přebírá ř́zení prrípadu pacienta a odpovídající } \\
\text { výkony péče) }\end{array}$ \\
\hline Oborová organizovanost & $\begin{array}{l}\text { Výzkum: All Ireland } \\
\text { Institute of Hospice and } \\
\text { Palliative Care (Ce- } \\
\text { loirský institut hospi- } \\
\text { cové a paliativní péče, } \\
\text { AIIHPC) } \\
\text { Jednotlivci: Irish Asso- } \\
\text { ciation for Palliative } \\
\text { Care (Irská asociace pro } \\
\text { paliativní péći) } \\
\text { Poskytovatelé: není } \\
\text { Advocacy (lobbying): } \\
\text { Irish Hospice Founda- } \\
\text { tion (Irská hospicová } \\
\text { nadace) }\end{array}$ & $\begin{array}{l}\text { Výzkum: není } \\
\text { Jednotlivci: Česká společnost paliativní medicíny } \\
\text { ČLS JEP } \\
\text { Poskytovatelé: } \\
\text { Asociace poskytovatelů hospicové paliativní péče } \\
\text { (2005) } \\
\text { Fórum mobilních hospiců (2017) } \\
\text { Advocacy (lobbying): NF Avast, menší nadace } \\
\text { a nadační fondy, jednotlivé „zastřešující organiza- } \\
\text { ce, jednotliví poskytovatelé (Cesta Domů aj.) }\end{array}$ \\
\hline Advocacy & $\begin{array}{l}\text { př́stup top-down } \\
\text { (ústřední strategie je } \\
\text { rozpracována a apliková- } \\
\text { na v odborných kruzích, } \\
\text { v územních samosprá- } \\
\text { vách a jednotlivými po- } \\
\text { skytovateli a odborníky). }\end{array}$ & $\begin{array}{l}\text { bottom-up (dílčí iniciativy jsou prosazovány různě é } \\
\text { formovanými zájmovými proudy, bez systematické } \\
\text { koordinace, bez sdílené vize a společných cílù) }\end{array}$ \\
\hline
\end{tabular}

Základní zdroj inspirace může Česko čerpat $\mathrm{v}$ procesu tvorby a obsahu zprávy National Advisory Committee publikované v roce 2001 jako výsledek mezioborového dialogu zadaného Ministerstvem zdraví, která je dosud uznávanou vizí (a plánem) paliativní péče v Irsku. Obdobný základní dokument $\mathrm{v}$ Česku chybí, přestože existenci podobného dokumentu doporučuje i EAPC..$^{54}$

Paliativní péče je v Irsku a priori vnímána jako dodatečný „konzultační, resp. konziliárni“ prvek v systému služeb. V Česku je často vnímána jako vymezená (časem, potřebami, odpovědností či odborností) fáze či etapa poskytování služeb. Konziliární povaha částečně odstraňuje bariéry dostupnosti (destigmatizuje - akcentuje kvalitu života, eliminuje potřebu „tvrdých kritérií pro „předáni““ do paliativní péče, resp. „přebírání zpět z paliativní péče“). Působení aktérů mimo 
veřejnou správu a praxi paliativní péče $\mathrm{v}$ oblasti výzkumu (AIIHPC) a podpory rozvoje a inovací v paliativní péči (Irish Hospice Foundation) spolu s fungující jednotnou profesní organizací, která není pouze zájmovým sdružením organizací či poskytovatelů služeb, účinně podporují a facilitují účast všech subjektů na formování budoucí podoby paliativní péče (uživatelů, profesionálů, výzkumníků, akademiků i tvůrců politik).

\section{Kontakt}

\section{Ing. Mgr. Matěj Lejsal}

Univerzita Karlova

Fakulta humanitních studií

Katedra rízení a supervize $v$ sociálních a zdravotnických organisacích

Pátkova 2137/5,182 00 Praha 8 - Libeň

matej.lejsal@fhs.cuni.cz

\section{Mgr. Jiří Krejčí}

Univerzita Karlova

Fakulta humanitních studií

Katedra rízení a supervize $v$ sociálních a zdravotnických organisacích

Pátkova 2137/5,182 00 Praha 8 - Libeň

jirikrejci@centrum.cz 